\title{
Santos, Luís Cláudio Villafañe G. o dia em que adiaram o Carnaval: política externa e a construção do Brasil
}

Tereza Maria Spyer Dulci*

São Paulo: Ed. Unesp, 2010. 278p.

Luís Cláudio Villafañe G. Santos’ book impresses from the beginning with its title, which links the popular festival of Carnival to foreign policy, and also with its cover, an image of a stained glass window in the National Cathedral of Washington portraying Baron Rio Branco. Immediately we are led to perceive that the book's starting point is José Maria Paranhos da Silva Júnior, Baron Rio Branco, responsible for the consolidation of Brazilian territory, who appears in that set of stained glass windows with Bolívar and San Martín, among the heroes of South America.

In this book $O$ dia em que adiaram o Carnaval: politica externa e a construção do Brasil, published by Editora Unesp, the author, a career diplomat, with a Master's and Doctorate from Universidade de Brasília, has written an excellent study of the relationship between nationalism, identity and foreign policy. Starting with Rio Branco, Villafañe runs through a historic panorama of the country, from the nineteenth century to the current day, to investigate how 'national consciousness,' the 'idea of the Brazilian race,' the 'consciousness of national backwardness' and the 'natural leadership' of Brazil in Latin America were constructed.

The postponement of popular festivities in 1912 due to the death of Baron Rio Branco, which had occurred on the eve of carnival, demonstrates the prestige and the power of the diplomat not only with authorities, but also with the general population. For Villafañe this was a unique case in history, in which the figure of a diplomat became a reference for the construction of a nation by obtaining important victories in frontier disputes.

Although they were not contemporaries, Bolívar, San Martín and Rio Branco were, each in their own way, responsible for the consolidation of

\footnotetext{
* Doctoral Student, Department of History, FFLCH/USP; Fapesp Grantee. Av. Prof. Dr. Lineu Prestes, 338 - Cidade Universitária. 05508-000 São Paulo - SP - Brasil. terezaspyer@hotmail. com
} 
nationalities in South American. What is immediately obvious is that in the case of Brazil, the figure of the Republic and not the Empire was the protagonist of this process of the construction of the Brazilian nation. But how can the place occupied by Rio Branco in the memory and imagination of the Brazilian nation, almost a century after the process of independence, be explained?

Villafañe states that Brazilian independence occurred without the presence of the famous 'liberators' of other American countries, and that the Empire had created a feeling of a common patria still connected to dynastic legitimacy, in the molds of European Ancien Regime, which explains the low level of adhesion to the feeling of national identity. This changed with the Republic, a moment in which it was sought to develop a national Brazilian feeling connected to the 'imagined community,' Benedict Anderson's concept, which the author draws on numerous times in the book.

In arguing that foreign policy is one of the most characteristic aspects of state action in the construction of nationalism, Villafañe highlights that the question of territory shapes the Brazilian 'national interest,' since it is one of the essential elements which the author calls the "holy trinity of nationalism," composed of "state, people and territory."

In turn the identity of a state, helped by its foreign policy, is often constructed through its relationship with other states, thus the importance of the concept of 'otherness,' which leads researchers to investigate not only what are the external 'others,' but also the internal 'others,' According to Villafañe, in the attempt to create an 'imagined Brazilian community,' the "other can assume various forms: Brazilians versus Portuguese, Brazilians versus Africans, America versus Europe, empire versus republic, civilization versus barbarity, continental versus particular nationalisms."

The central objective of the first generations of intellectuals in the Republic was to reinsert Brazil in America and overcome the 'backwardness' caused by colonization and the Portuguese monarchy. The author identifies in this context two strands of debate about Brazilian identity which engendered the ideas of 'national backwardness:' one based on relations between the environment and race (which valorized racial intermixing) and another based on an anti-Portuguese and anti-African vision (which valorized Americanism).

The historian states that with the advent of the Republic, the place of Brazil on the continent was transformed, especially through the incorporation of the premises of Pan-Americanism, dear to Brazilian foreign policy, notably during the time of Rio Branco as foreign minister between 1902 and 1912.

According to the author the diplomacy of Rio Branco is paradigmatic to 
understand the relationship between nationalism and territoriality, since they seek to define frontiers, increase the international prestige of Brazil and affirm the 'natural' leadership of Brazil in South America, leaving as an inheritance a 'bible' which described Brazil as a "peaceful country with defined frontiers, territorially satisfied.” An interesting example, analyzed by the historian, was the presence of Brazil in the work of the League of Nations, whose aim was to increase the international prestige of the country, but which contributed at the same time to the political sustenance of the government and to strengthening the rivalries between Brazil and Argentina in the dispute for political and military preponderance in the Southern Cone.

Villafañe also highlights the Estado Novo as a strong instrumentalizer of national identity, since in this period there occurred a process of consolidation of the cultural symbols of current Brazilian identity: carnival and football. Through the Department of Press and Propaganda - the body responsible for helping "popular festivities with a patriotic, educational, or touristic propaganda purpose" - Getúlio Vargas institutionalized carnival, making it officially a symbol of Brazilian nationality, and professionalized football with the purpose of diffusing a set of values supposedly belonging to a national character, "product of a Brazilian soul."

Also from the Vargas Era onwards, nationalism was linked to the idea of economic and social development, which according to the author "added a new element to the Baron's bible." The development sponsored by the state would lead to the overcoming of the backwardness and project Brazil to the future in developing an 'autonomy of dependency,' a component absent from foreign policy in both in the Empire and the Old Republic.

It was at this moment when, according to Villafañe, Brazilian diplomatic rhetoric incorporated the idea of belonging to Latin America, when it perceived itself as a member of a group of less developed countries and sought to overcome the 'national backwardness'. In this phase the historian highlights national developmentalism, characteristic of the governments of Juscelino Kubitschek, Jânio Quadros and João Goulart; he analyzes the theory of modernization, created by US academia in post-Second World War era (which contrasts 'modern' and 'traditional' societies) and explains why the United States became the 'other,' in contrast with Latin American identity.

As a result of the Independent Foreign Policy, at the beginning of the 1960s, Brazil abandoned the 'unwritten alliance' with the United States, reinforced Latin-American identity and developed affinities with Africa and Asia, which were experiencing the decolonization process. The author 
highlights this period, though he does not forget to consider the fact that continental American identity was used by the United States as a form of control by excluding Cuba from the inter-American system in function of its political system, 'incompatible' with the other American countries.

Finally, in analyzing the Military Dictatorship, the historian emphasizes the position of the alignment of Brazil with the United States (a return to the former standards of foreign policy) and emphasizes the anti-communist and nationalist discourse of the military (who saw Brazil as a 'regional power'). Moreover, Villafañe highlights the return and the strengthening of Latin American identity between the end of the twentieth century and the beginning of the twenty-first, discussing how nations are invented and updated according to different historical contexts.

The author ends the book in a slightly provocative tone, questioning whether Rio Branco's bible has been ruptured. The great panorama carefully presented by Villafañe allows us to compare the different periods in our history, leading us to understand the complex relations of power of different identity projects and the 'imagined community' which is Brazil. Even for those who disagree with the author's premises and theses of the author, this lucid and instigating work points to new paths of reflection on the inbuilt relations between foreign policy and the long and incessant 'construction' of Brazil.

Review received on July 8, 2011. Approved on October 10, 2011. 